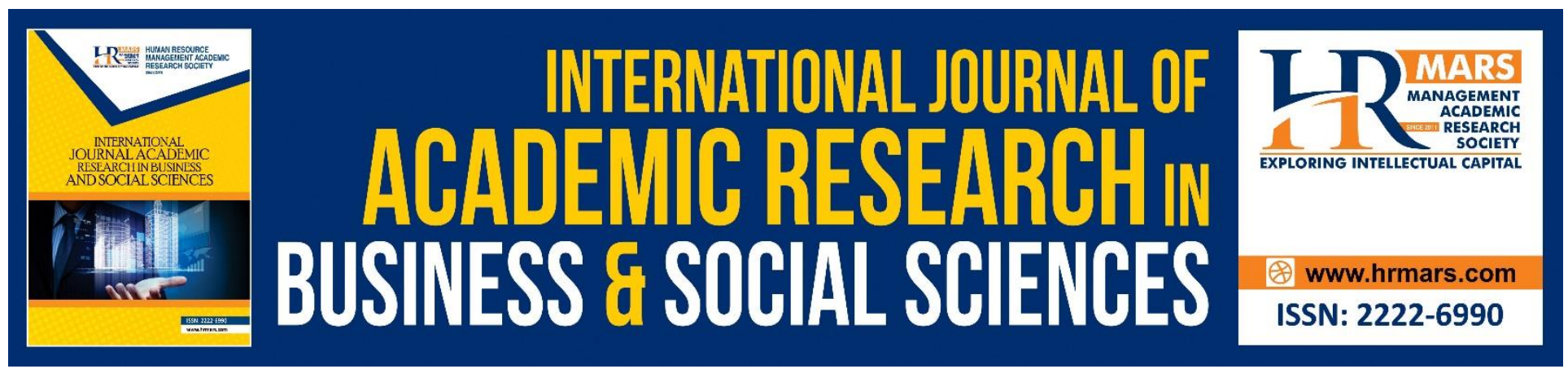

\title{
The Concept of Theory of Dynamic Capabilities in Changing Environment
}

\section{Zurina Samsudin, Md Daud Ismail}

To Link this Article: http://dx.doi.org/10.6007/IJARBSS/v9-i6/6068

DOI:10.6007/IJARBSS/v9-i6/6068

Received: 19 April 2019, Revised: 12 May 2019, Accepted: 01 June 2019

Published Online: 25 June 2019

In-Text Citation: (Samsudin \& Ismail, 2019)

To Cite this Article: Samsudin, Z. binti, \& Ismail, M. D. (2019). The Concept of Theory of Dynamic Capabilities in Changing Environment. International Journal of Academic Research in Business and Social Sciences, 9(6), 1071-1078.

\section{Copyright: (C) 2019 The Author(s)}

Published by Human Resource Management Academic Research Society (www.hrmars.com)

This article is published under the Creative Commons Attribution (CC BY 4.0) license. Anyone may reproduce, distribute, translate and create derivative works of this article (for both commercial and non-commercial purposes), subject to full attribution to the original publication and authors. The full terms of this license may be seen at: $\underline{\text { http://creativecommons.org/licences/by/4.0/legalcode }}$

$$
\text { Vol. 9, No. 6, 2019, Pg. } 1071-1078
$$




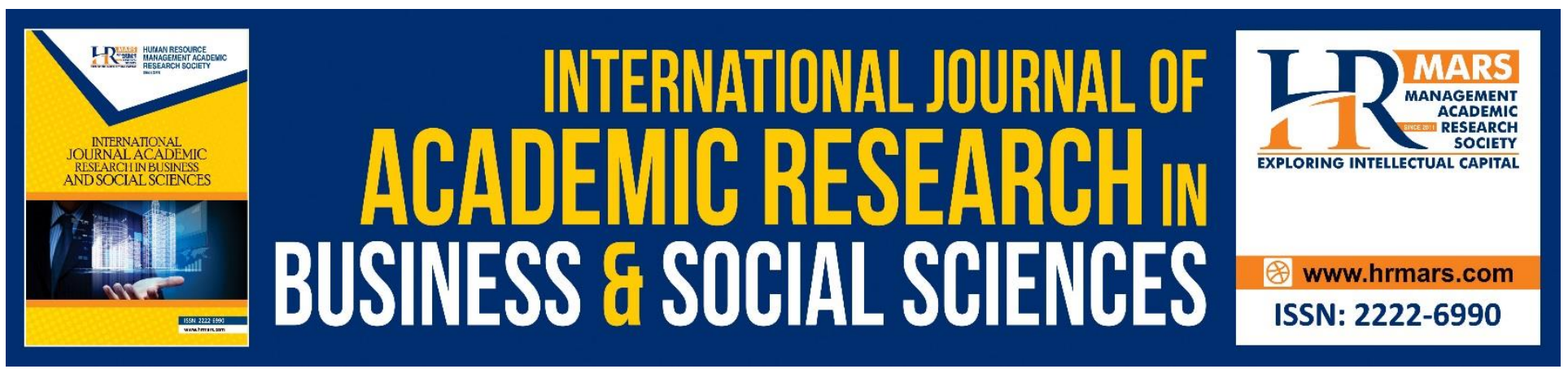

\title{
The Concept of Theory of Dynamic Capabilities in Changing Environment
}

\author{
Zurina binti Samsudin, MD Daus Ismail \\ Universiti Kebangsaan Malaysia, Bangi, Malaysia
}

\begin{abstract}
The theory of resource-based view (RBV) explain the firm competitive advantage through the uniqueness, rare and imitable resources that the firm created which lead to firm growth. Apart from that, the RBV only explain the firm competitive advantage in the static environment and this has become a limitation especially when the firm is dealing in the fast and changing market environment. On the other hand, theory of dynamic capability explain the firm competitive advantage from the perspective of dynamic and fast-moving environment and has received much attention from the international business scholar since 1990s. Dealing in international business market has involve different environmental background, and in order for the firm to cope with this differences, the firm need to develop specific capabilities and continuous learning. It is important for the firm to remain relevant and competitive in the market especially when doing the business outside the home country. Keywords: Dynamic, Environment, Competitive Advantage, Capabilities, Export.
\end{abstract}

\section{Introduction}

The review of literature on export performance begin in year 1978 by Bilkey and continue by Zou and Stan (1998) followed by Sousa, Martinez-Lopez and Coelho in year 2008. The last review of export performance which is the current and latest review done by Chen, He and Sousa (2016) from 2006 until 2014 stated and increasing number of papers from 52 to 124 papers. Shown that exporting has received a bigger attention from scholars and a large body of literature is focus on it (Hasaballah, et al., 2019) especially in the area of export performance (e.g: Pinho, 2016). Chabowski et al., 2018 conducted a study on the exporting literature from 1958 until 2016. Based on the current review by Chen et al., (2016), the most dominant theory is Resource-based View (RBV) with 50 studies, contingency theory with 13 studies, institutional-based view (IBV) with 12 studies, and organizational learning theory (OLT) with 11 studies. Although RBV is the most popular theory in previous research, it has its limitations especially in explaining the dynamic development process (Khan and Lew, 2018). Global business is facing dynamic and unpredictable environment, hence in order for the firm to sustain and be competitive and relevant in the market, the firm need to be proactive towards the changing environment (Efrat, et.al 2018). 
Due to the changes and rapid development of international business environment, it is relevant and strongly advisable to adapt to the changing environment by looking at a dynamic perspective. Having said that, the theory of dynamic capabilities has come to rescue by explaining the firm competitive advantage in the dynamic environment.

\section{Dynamic Capabilities Theory}

Dynamic capabilities theory proposed by Teece and Pisano (1994) is the extension from resource-based view (RBV) of the firm (Barney, 1986, 1991). Based on the RBV, firm in the similar industry perform differently because they have different kind of resources and capabilities (Barney, 1986, 1991; Peretaf, 1993) whereby RBV is considered as static in nature and insufficient to explain the competitive advantage of the firm in changing market environment (Priem \& Butler, 2001). Additionally, the resource based view of the firm is looking at the unique, rare and imitable resources that the firm has that created competitive advantage and firm growth (Barney, 1986) however, the process of maintaining competitive advantage is limitless and it is the dynamic process (Hung, Yang, Lien, McLean, \& Kuo, 2010), hence scholars has proposed that in order for the firm to remain competitive in the market, the firm need to develop specific capabilities and continuous learning (Argyris \& Schon, 1978; Hammer, 2001; Jashapara, 1993; Senge, 1990; Zott, 2003) which is from dynamic capabilities point of view especially in the new or changing market environment (Wilden, Gudergan, Nielsen, \& Lings, 2013). The lack of dynamic capabilities will prohibit the firm to maintain their competitive advantage especially in the changing environment (Gnizy, Baker, \& Grinstein, 2014). The application of dynamic capabilities in the past literature has shown an increasing interest by the scholars since the foundation of international ambidexterity literature (Hsu, Lien, \& Chen, 2013; Luo, 2002; Luo \& Rui, 2009; Prange \& Verdier, 2011) which explain ambidexterity as the firm capability to respond to the environmental complexity and international experience in the field of international business (Hsu et al., 2013).

The definition of dynamic capabilities as define by Teece, Pisano, and Shuen (1997) is the ability of the firm to combine, develop and reconfigure external and internal expertise in order to respond to speedily changing environment. Previous research has provide significant definition on dynamic capabilities. Eisenhardt and Martin (2000) define dynamic capabilities as the process of use resources to create new resources that can create market change. Market is change when the market is evolve, emerge, split or even die. Apart from that, dynamic capabilities is the results of the alteration of resources that been acquire, integrated and recombine that develop new creation of strategies (Grant, 1996b; Pisano, 1994). Hence, dynamic capabilities is the factor of the creation of new sources of competitive advantage (Henderson \& Cocburn, 1994; Teece et al., 1997). Previous researcher perceived dynamic capabilities as the way on how to solve inflexibility in capabilities (Schreyogg \& Kliesch-Eberl, 2007), how to utilize and make use of the knowledge (Easterby-Smith \& Prieto, 2008) and some even agreed that dynamic capabilities can explain how firms respond to change (Newey \& Zahra, 2009) especially from the environmental context.

The relationship between dynamic capabilities and organizational performance has indicate a positive relationship based on empirical studies (Hung et al., 2010). For example, Danneels (2002) conducted a study on five high-tech firms and found that product innovation capabilities increase the firm competencies and performance. Apart from that, Zott (2003) identified how the different 
dynamic capabilities of the firm can influence the performance and the study further identified that even in small different of dynamic capabilities between the firm, it can create significantly divergence in firm performance. From international business perspective, Luo (2000) discovered that the exploitation of dynamic capabilities can increase the firm expansion in international market and simultaneously increase firm performance.

Early proposition of dynamic capabilities stating that it has a direct relationship with firm's performance (Teece et al., 1997). Additionally, Zollo and Winter (2002) define the direct relationship between firm performance and dynamic capabilities and emphasized that if the firm has no dynamic capability in the changing environment, the superiority and the survival of the firm will remain temporary. This has been supported by Teece (2007) whereby the development of dynamic capabilities is to identify the sources of firm's competitive advantage at the enterprise-level and it is determine by the firm success or failure.

On the other hand, other researchers debated on the direct link between dynamic capabilities and firm performance. For instance, Eisenhardt and Martin (2000) argue that dynamic capabilities alone does not guarantee the firm's competitive advantage, but the arrangement and the positioning of the firm's resources created by dynamic capabilities is more skillful than competition. This also supported by Zott (2003) mentioned that modification and the alteration of the firm's resources through dynamic capabilities influence the firm performance and not the dynamic capabilities stand alone. Additionally, Eisenhardt and Martin (2000) proposed that the firm that has dynamic capabilities will have an advantage towards their competitor who does not have that capabilities while Zott claim that the firm that has distinguished dynamic capabilities may develop different kind of resources and as a results produced differentiated performance levels.

Apart from that, it is important to know that dynamic capabilities is not the same as specific capabilities such as supply chain, R\&D and marketing (Gnizy et al., 2014), in fact this dynamic capabilities is served as a medium to explore resources and capabilities that required to remain competitive especially in the changing market environment (Wilden et al., 2013). Dynamic capabilities also has been associated with tacit organizational elements such as routines, processes, managerial, cognition and knowledge (Easterby-Smith, Lyles, \& Peteraf, 2009) and also adaptive, absorptive and innovative capability (Grant, 1996a; Pisano, 1994; Wang \& Ahmed, 2007).

Dynamic capabilities also has been a focus area especially in the field of strategic management (Barreto, 2010) and the firm success is not only depend on the resources and capabilities that the firm has, but most importantly on how the firm adjust themselves with the market they operated (Rua, Franca, \& Fernandez Ortiz, 2018). It is important to note that dynamic capabilities is not separated from resource-based view, however it is another important element in explaining competitive advantage especially in the changing environment (Ambrosini \& Bowman, 2009; Barreto, 2010; Eisenhardt \& Martin, 2000; Wang \& Ahmed, 2007). Additionally, in the turbulence and fast growing market, the firm resources must be dynamic and the managers need to know how to adjust the strategy with the environment in order to create new skills that can meet the dynamic of the market (Monteiro, Soares, \& Rua, 2017).

The trend of research especially in the field of export has begun since year 1958 and the assessment of export research done by Chabowski et al. (2018) indicated four general trends. The first trend of export research from year 1958 until 1992 is focus on pre-export activity and export 
behavior. The second trend started from year 1993 until 2002 focus on the knowledge development and internationalization. The third trend on the export research is focus on the export management, strategy and performance from year 2003 until 2012 and the fourth trend which is the latest and current trend on export research is focus on dynamic capability as the area of concern in export research from year 2013 until 2016.

This study is supported by Chabowski study on the assessment on export research in current trend which is dynamic capability. In international business studies, the theory of dynamic capability has been previously used to determine the international experience and ownership strategy relationship as dynamic capability (Tang \& Gudergan, 2018). Apart from that, Xu, Guo, Zhang, and Dang (2018) identified another component of dynamic capabilities which is dynamic marketing capabilities from the perspective of inter-organizational relationship and entrepreneurial orientation factors and the study explore the dynamic marketing capabilities in domestic versus overseas market. The implementation of dynamic capabilities from the international business perspective also can be used to develop a model of export capabilities such as adaptability, innovativeness, unpredictability and task-flexibility in order to achieve competitive advantage and export performance (Efrat, Hughes, Nemkova, Souchon, \& Sy-Changco, 2018).

The exploration of dynamic capabilities also has been used not only for the study of export, but also another mode of entry which is franchisee (El Akremi, Perrigot, \& Piot-Lepetit, 2015) and international new ventures (Oxtorp, 2014) as well as born-global firm in determining dynamic capabilities emerged as a result of a mix of experiential and deliberate learning process in changing domestic and international business environments (Kumar \& Yakhlef, 2014). Knowledge (Dong, Yu, \& Zhang, 2016; Maes \& Sels, 2013; Nonaka, Hirose, \& Takeda, 2016) and entrepreneurial capabilities (Andersson \& Evers, 2015; Bouncken, Lehmann, \& Fellnhofer, 2016; Fitz-Koch \& Nordqvist, 2017; Lanza \& Passarelli, 2014; Swoboda \& Olejnik, 2016) also has been extensively studied from the perspective of dynamic capability from international business context which indicate that the theory of dynamic capabilities has received extensive attention from the scholars especially in the field of international business.

\section{Conclusion}

The discussion on the theory of dynamic capability has enlighten the history and the development of the theory of dynamic capabilities in the changing environment. The theory of dynamic capability is not to replace the existing theory of resource-based view (RBV), this theory is however extending the current usage of RBV in explaining the firm competitive advantage in dynamic environment.

Dealing with international business is much more challenging than doing business in domestic market. The different characteristic from customer behavior to institutional behavior will directly affect the business performance. The application of the theory of dynamic capability has been used extensively to discuss on the competitive advantage in the dynamic environment especially in international business.

When the firm decided to expand the business outside the home country, the firm need to be adaptable to the changes and willing to make a change for the sustainability of the firm. Hence, 
INTERNATIONAL JOURNAL OF ACADEMIC RESEARCH IN BUSINESS AND SOCIAL SCIENCES

Vol. 9, No. 6, June, 2019, E-ISSN: 2222-6990 @ 2019 HRMARS

this is where the theory of dynamic capabilities come into the picture in explaining the dynamic environment in international business.

\section{References}

Ambrosini, V., \& Bowman, C. (2009). What are dynamic capabilities and are they a useful construct in strategic management? International Journal of Management Reviews, 11(1), 29-49.

Andersson, S., \& Evers, N. (2015). International opportunity recognition in international new ventures- a dynamic managerial capabilities perspective. Journal of International Entrepreneurship, 13(3), 260-276.

Argyris, C., \& Schon, D. (1978). Organizational learning: a theory of action perspective. [Press release]

Barney, J. B. (1986). Strategic factor markets: expectations, luck and business strategy. Management Science, 32, 1231-1241.

Barney, J. B. (1991). Firm resources and sustained competitive advantage. Journal of Management, 17(1), 99-120.

Barreto, I. (2010). Dynamic capabilities: A review of past research and an agenda for the future. Journal of Management, 36(1), 256-280.

Bouncken, R. B., Lehmann, C., \& Fellnhofer, K. (2016). The role of entrepreneurial orientation and modularity for business model innovation in service companies. International Journal of Entrepreneurial Venturing, 8(3), 237-260.

Chabowski, B., Kekec, P., Morgan, N. A., Hult, G. T. M., Walkowiak, T., \& Runnalls, B. (2018). An assessment of the exporting literature: using theory and data to identify future research directions. Journal of International Marketing, 26(1), 118-143.

Danneels, E. (2002). The dynamics of product innovation and firm competences. Strategic Management Journal, 23(12), 1095-1121.

Dong, X., Yu, Y., \& Zhang, N. (2016). Evolution and coevolution: dynamic knowledge capability for catching-up in emerging economies. Management and Organization Review, 12(4), 717-745.

Easterby-Smith, M. E., Lyles, M., \& Peteraf, M. A. (2009). Dynamic capabilites: current debate and future directions. British Journal of Management, 20(1), 1-8.

Easterby-Smith, M. E., \& Prieto, I. (2008). Dynamic capabilities and knowledge management: an integrative role for learning? British Journal of Management, 19(3), 235-249.

Efrat, K., Hughes, P., Nemkova, E., Souchon, A. L., \& Sy-Changco, J. (2018). Leveraging of dynamic export capabilities for competitive advantage and performance consequences: Evidence from China. Journal of Business Research, 84, 114-124.

Eisenhardt, K., \& Martin, J. (2000). Dynamic capability: What are they? Strategic Management Journal, 21, 1105-1121.

El Akremi, A., Perrigot, R., \& Piot-Lepetit, I. (2015). Examining the drivers for franchised chains performance through the lens of dynamic capabilities approach. Journal of Small Business Management, 53(1), 145-165.

Fitz-Koch, S., \& Nordqvist, M. (2017). The reciprocal relationship of innovation capabilities and socioemotional wealth in a family firm. Journal of Small Business Management, 55(4), 547570. 
INTERNATIONAL JOURNAL OF ACADEMIC RESEARCH IN BUSINESS AND SOCIAL SCIENCES

Vol. 9, No. 6, June, 2019, E-ISSN: 2222-6990 @ 2019 HRMARS

Gnizy, I., Baker, W. E., \& Grinstein, A. (2014). Proactive learning culture: A dynamic capability and key success factor for SMEs entering foreign market. International Marketing Review, 31(5), 477505.

Grant, R. M. (1996a). Prospering in dynamically-competitive environments: organizational capability as knowledge integration. Organization Science, 7(4), 375-387.

Grant, R. M. (1996b). Toward a knowledge-based theory of the firm. Strategic Management Journal(17), 109-122.

Hammer, M. (2001). The agenda: what every business must do to dominate the decade. [Press release]

Henderson, R., \& Cocburn, I. (1994). Measuring competence? Eploring firm effects in pharmaceutical research. Strategic Management Journal, 15(1), 63-84.

Hsu, C., Lien, Y., \& Chen, H. (2013). International embidexterity and firm performance in small emerging economies. Journal of World Business, 48, 58-67.

Hung, R. Y. Y., Yang, B., Lien, B. Y. H., McLean, G. N., \& Kuo, Y.-M. (2010). Dynamic capability: impact of process alignment and organizational learning culture on performance. Journal of World Business, 45(3), 285-294.

Jashapara, A. (1993). The competitive learning organization: a quest for the Holy. Management Decision, 31(8), 52-63.

Kumar, N., \& Yakhlef, A. (2014). How capabilities evolve in a born global firm. Journal of Entrepreneurship in emerging economies., 6(3), 223-242.

Lanza, A., \& Passarelli, M. (2014). Technology change and dynamic entrepreneurial capabilities. Journal of Small Business Management, 52(3), 427-450.

Luo, Y. (2000). Dynamic capabilities in international expansion. Journal of World Business, 35(4), 355378.

Luo, Y. (2002). Capability exploitation and building in a foreign market: implications for multinational enterprise. Organization Science, 13, 48-63.

Luo, Y., \& Rui, H. (2009). An ambidexterity perspective towards multinational enterprises from emerging economies. Organization Science, 13, 48-63.

Maes, J., \& Sels, L. (2013). SMEs radical product innovation: the role of internally and externally oriented knowledge capabilities. Journal of Small Business Management, 52(1), 141-163.

Monteiro, A., Soares, A. M., \& Rua, O. L. (2017). Entrepreneurial orientation and export performance: the mediating effect of organizational resources and dynamic capabilites. JOurnal of International Business and Entrepreneurship Development, 10(1), 3-19.

Newey, L., \& Zahra, S. A. (2009). The evolving firm: how dynamic and operating capabilites interact to enable entrepreneurship. British Journal of Management, 20(1), 81-100.

Nonaka, I., Hirose, A., \& Takeda, Y. (2016). 'Meso'- Foundation as dynamic capabilities: team-level synthesis and distributed leadership as the source of dynamic creativity. Global Strategy Journal, 6(3), 168-182.

Oxtorp, L. A. (2014). Dynamic managerial capability of technology-based international new venturesa basis for their long term competitive advantage. Journal of International Entrepreneurship, 12(4), 389-420. 
Peretaf, M. (1993). Th cornerstones of competitive advantage: a resource-based view. Strategic Management Journal, 14(3), 179-191.

Pisano, G. P. (1994). Knowledge, integration, and the locus of learning: an empirical analysis of process development. Strategic Management Journal(15), 85-100.

Prange, C., \& Verdier, S. (2011). Dynamic capabilities, internationalization process and performance. Journal of World Business, 46(1), 126-133.

Priem, R. L., \& Butler, J. E. (2001). Is the resource-based "view" a useful perspective for strategic management research? Academy of Management Review(26), 22-40.

Rua, O., Franca, A., \& Fernandez Ortiz, R. (2018). Key drivers of SMEs export performance: the mediating effect of competitive advantage. Journal of Knowledge Management, 22(2), $257-$ 279.

Schreyogg, G., \& Kliesch-Eberl, M. (2007). How dynamic can organizational capabilities be? Toward a dual-process model of capability dynamization. Strategic Management Journal, 28(9), 913933.

Senge, P. (1990). The leader's new work: building learning organizations. Sloan Management Review, 32(1), 7-23.

Swoboda, B., \& Olejnik, E. (2016). Linking processes and dynamic capabilities of international SMEs: the mediating effect of international entreprenuerial orientation. Journal of Small Business Management, 54(1), 139-161.

Tang, R. W., \& Gudergan, S. P. (2018). A meta-analysis of of the international entrepreneurshipownership strategy relationship: A dynamic capabilities view. Management International Review, 58(4), 541-570.

Teece, D. J. (2007). Explicating dynamic capabilities: the nature and microfundations of (sustainable) enterprise performance. Strategic Management Journal, 28, 1319-1350.

Teece, D. J., \& Pisano, G. (1994). The dynamic capabilities of firms: an introduction. Industrial and Corporate Change, 3(3), 537-556.

Teece, D. J., Pisano, G., \& Shuen, A. (1997). Dynamic capabilities and strategic management. Strategic Management Journal, 18(7), 509-533.

Wang, C. L., \& Ahmed, P. K. (2007). Dynamic capabilities: a review and a research agenda. International Journal of Management Reviews, 9(1), 31-51.

Wilden, R., Gudergan, S. P., Nielsen, B., \& Lings, I. (2013). Dynamic capabilites and performance: strategy, stucture and environment. Long Range Planning, 46(1), 72-96.

Xu, H., Guo, H., Zhang, J., \& Dang, A. (2018). Facilitating dynamic marketing capabilities development for domestic and foreign firms in an emerging economy. Journal of Business Research, 86, 141-152.

Zollo, M., \& Winter, S. G. (2002). Deliberate learning and the evolution of dynamic capabilities. Organizational Science, 13, 339-351.

Zott, C. (2003). Dynamic capabilities and the emergence of intraindustry differential firm performance: insights from a simulation study. Strategic Management Journal, 24, 97-125. 